\title{
Landscapes as Narrative Commentary in Cormac McCarthy's Blood Meridian or the Evening Redness in the West
}

Dianne C. Luce

\section{(2) OpenEdition}

\section{Journals}

Electronic version

URL: https://journals.openedition.org/ejas/12259

DOI: 10.4000/ejas.12259

ISSN: 1991-9336

Publisher

European Association for American Studies

Electronic reference

Dianne C. Luce, "Landscapes as Narrative Commentary in Cormac McCarthy's Blood Meridian or the Evening Redness in the West", European journal of American studies [Online], 12-3 | 2017, Online since 12 December 2017, connection on 08 July 2021. URL: http://journals.openedition.org/ejas/12259 ; DOI: https://doi.org/10.4000/ejas.12259

This text was automatically generated on 8 July 2021 .

Creative Commons License 


\title{
Landscapes as Narrative
} Commentary in Cormac McCarthy's Blood Meridian or the Evening Redness in the West

\author{
Dianne C. Luce
}

1 The ways in which Cormac McCarthy's knowledge of visual art informs his writing is a fruitful area of study that has evolved slowly over the past two decades and is now beginning to receive the detailed attention it deserves in studies of various art genres in McCarthy's fiction. Early on, Robert Jarrett briefly noted that McCarthy's landscapes "derive from... luminism, which extends from Emerson to Frederic Church, then from Church to the landscape painters and seaside photographers of the late nineteenth century and early modernism, and which culminates in Ansel Adams's black and white photographic landscapes" (36-40). More recently, in ground-breaking articles Randall Wilhelm identifies and explores the implications of the pattern of still life imagery in The Road (2006) and examines McCarthy's engagement with the picture book genre in All the Pretty Horses (1992). ${ }^{1}$ In the Suttree (1979) chapter of Reading the World: Cormac McCarthy's Tennessee Period (2009), I discuss the ways in which Suttree's attention to photographs, not only his studying portraits of the dead but also his habit of capturing evocative images of the living within the frames of windows, reflects "his obsessions with death and his regretted or repudiated past" (217-226). In that chapter I do not relate McCarthy's trope of photographs to art history, but in "The Painterly Eye: Waterscapes in Cormac McCarthy's The Road" (2012) I follow up on both Jarrett's observations about the influence of luminism on McCarthy and Wilhelm's model of reading some of McCarthy's scenes as painterly still lives, to discuss the ways in which McCarthy's waterscapes reflect the iconography and techniques of nineteenth-century American painters and express the father's sense of extreme loss. My aim here is to build on Wilhelm's and my earlier studies of McCarthy's still, framed artistic images to argue that McCarthy not only reflects or subverts landscape paintings and techniques in his fiction, but that he deploys his landscapes in Blood Meridian as one means of 
narrative commentary that transcends its often fairly objective narrative stance. In doing this, I am also influenced by Christopher White's "Reading Visions and Visionary Reading in Blood Meridian" [2013], in which he applies the ideas of reading theorists Christopher Collins, Elaine Scarry and others to McCarthy's novel. of particular interest for my project is White's argument that McCarthy's prose mimics the perceptual act and thus is a guide for the reader's mental construction or performance of the fiction (179). Specifically, I want to argue that some of McCarthy's landscape descriptions in Blood Meridian ask the reader to envision the scenes as painterly landscapes and apply to them the strategies one would employ to interpret a painting.

2 A notable characteristic of McCarthy's blood-soaked Blood Meridian is the illusion of ethical neutrality in its narrator, who usually reports the egregious violence of the Glanton gang and the Indians who oppose them with a seemingly dispassionate gaze, who seldom indulges in direct judgments, and who trusts his reader to draw his or her own conclusions based on what is "seen." Together with the pyrotechnics of McCarthy's style, such narrative reticence has prompted some to interpret the novel as a celebration of violence that revels in the inventive cruelty of the period of American history when the young nation pursued its Manifest Destiny. Certainly the exuberance and grotesque humor of the "death hilarious" Comanche attack on White's force (53) might support such a reading. But another feature of the novel, the unusual prominence of its descriptions of the land, asks us to join the narrator in his undertaking to see the west, human nature, and the violent claiming of an American empire with an intensity of vision and sobriety of gaze that counters the impression we may initially have of the narrator's ethical objectivity. This narrator proves highly contemplative, highly engaged, and deeply troubled by the object of his meditation. Often his landscape descriptions function as oblique narrative commentary on the gang's enterprise; they do so by deploying painterly techniques and sometimes by alluding to or deconstructing particular paintings-often the works of nineteenthcentury American landscape painters who contributed to establishing the cultural identity of the American nation "through the symbolic content of form and composition" (Miller 2). In Blood Meridian, McCarthy creates landscapes that are not merely documentary scenery or seasonal settings but are constructed to be read thematically as paintings might be.

3 McCarthy usually reflects painterly traditions in his writing quite obliquely. Although he refers to painting terms and artistic media, and sometimes invents fictional paintings and photographs, he almost never refers to artists or artworks by name. Nevertheless, the brooding narrator of this novel dominated by landscape depiction demonstrates habits of seeing that are deeply informed by traditions of painting and art history. McCarthy's most painterly landscape passages not only reflect artistic traditions of spatial composition, but may also subtly evoke the imagery of well-known artworks. Furthermore, they often participate in and subvert the iconography of nineteenth-century American national images presented in artwork of the period.

\section{McCarthy and Art: The Biographical Evidence}

4 Considerable evidence establishes McCarthy's awareness of European and American traditions of painting and sculpture as well as his own artistic ability. Wilhelm cites some of the published evidence ("McCarthy as Verbal Illustrator" 335, 339-340), and 
quite a bit more surfaces in unpublished interviews and letters. We know that McCarthy, like Judge Holden, is a fairly accomplished draftsman, and that his drawings date back to his childhood, when he created "big, showy paintings" of animals and geological phenomena such as an erupting volcano for local art exhibits. Indeed, he recalled, "I was very good... a child artist. A wunderkind," which suggests that his childhood identity was partly defined through his artistic ability (Jurgensen W1). The desire to create visual art endured into his high school years. In a one-paragraph sketch of "Charlie McCarthy" in November 1948 that was likely written by his sister Barbara McCarthy, coeditor of Catholic High School's school paper, she mentioned that painting and cartooning were two of McCarthy's many interests (qtd. in Morgan 7). And he is listed as artist on the staff of the Gold and Blue in 1950/51, although neither Wesley Morgan nor I have been able to find any drawings signed by McCarthy in the issues we have seen. ${ }^{2}$

$5 \quad$ As an adult McCarthy continued to employ his drawing and design skills in a variety of ways even though writing became the primary expression of his creativity. In the early 1970s he responded to Burt Britton's request for a self-portrait by sketching a cartoon of himself gleefully working at his manual typewriter, his brain wired up, his irises weirdly slanted at a diagonal, and with the caption, "Them old dreams are only in your head" (Britton 33). McCarthy told interviewer Mark Owen he had "always been interested in architectural design" when they discussed his remodeling of an old dairy barn as his home in Louisville, Tennessee (4B); and his artist friend Bill Kidwell (d. 2015) recalled that McCarthy did architectural drawings as well as stonemasonry when they worked together on construction projects in Nashville, where McCarthy lived for at least nine months in 1979 (Arnold and Luce; McCarthy to Woolmer, letters postmarked Nashville, 2 Feb. and 5 Nov. 1979). In addition, McCarthy's papers show that he has sometimes employed his drawing ability to illustrate various objects for his editors. For example, on the editorial copy of the revised typescript of The Orchard Keeper (1965), McCarthy drew a "schematic" of the pleating in Sylder's shirt for Albert Erskine (9 verso). And he later drew a sketch of the fireplace he was building in his house in El Paso in a letter to his copy-editor Bertha Krantz. ${ }^{3}$ Similarly the French translator of Blood Meridian, François Hirsch, who established a working relationship with the writer, recalls McCarthy's illustrating his explanations of various passages in the novel (208).

Evidence of McCarthy's interest in cartoonists appears in a letter Erskine received on March 31, 1964. McCarthy asked his editor if he had ever encountered the cartoons of Fernando Krahn (1935-2010) that were running in The Reporter, an influential liberal magazine published in New York bi-weekly between 1949 and 1968 that commented on national and international politics and regularly published book reviews. Krahn was a Chilean-born artist who lived in New York City in the 1960s and published cartoons not only in The Reporter but also The New Yorker, Atlantic, and Esquire. McCarthy especially recommended Krahn's “The Artist" (Oct. 24, 1963) and a series of four images entitled “The Hunt" (Jan. 30, 1964), all of which were later included in Krahn's 1965 compilation, The Possible Worlds of Fernando Krahn. In addition, in Books Are Made out of Books: A Guide to Cormac McCarthy's Literary Influences (2017), Michael Crews notes that McCarthy's reading notes for Cities of the Plain (1998) reveal he consulted the syndicated cartoons of James Robert Williams, collected in Cowboys Out Our Way (1951), for images of range life. Crews also calls attention to a note of appreciation McCarthy wrote in 2010 to Alexander Theroux for his biography of cartoonist and illustrator Edward Gorey. 
McCarthy's note is quoted on the back cover of Theroux's The Strange Case of Edward Gorey (Crews 241-242).

7 McCarthy's interest in viewing fine artwork and his willingness to train his eye are also clear. When he was in New York, either before embarking for Europe in August 1965 or on his return in October 1967, he went to the Museum of Modern Art, where he saw Brazilian surrealist Maria Martins' wood and bronze sculpture, The Road; The Shadow; Too Long, Too Narrow (1946). He was enough impressed by both the sculpture and its title, perhaps for their resonance with Outer Dark, that he recalled the work in a letter to Erskine about titling that novel (received Feb. 15, 1968). In New York McCarthy could also have seen nineteenth-century landscape paintings of the luminists and the Hudson River school at the New-York Historical Society and the Metropolitan Museum of Artlandscape paintings that influenced his own treatments of nature in his novels. Overseas he had the opportunity to spend considerable time in the museums of London and Paris, cities he visited on his tour of western Europe in 1965-68. ${ }^{4}$ Back in the US, in the fall of 1968 McCarthy and his wife Anne visited his parents in Virginia and spent several days in Washington, DC "looking at pictures" (Letter to Erskine, received 8 Nov. 1968). Here he could have seen yet more landscapes at the Smithsonian American Art Museum, and a letter he mailed to Bill Kidwell on November 6, 1968 reports that he and Anne spent five hours looking at the impressionist paintings in the National Gallery of Art. Historian Lawrence Levine (d. 2006) recalled that at one of the annual gatherings of MacArthur Foundation fellows in Chicago, when he and McCarthy visited an art museum together, he was impressed with how acute McCarthy's eye was-how adept he was at observing and reading the works.

Epistolary evidence reveals too that McCarthy once hoped to illustrate two of his novels with the artwork of others. When he returned from Europe McCarthy reconnected with Bill Kidwell, whom he had first met several years earlier. The two became neighbors in Rockford and then in Louisville, Tennessee; and in the summer of 1971, with a HUD urban renewal grant, they collaborated on the creation of two fifteen-foot circular mosaics of Tennessee marble and river rock designed by Kidwell and installed in the sidewalks of downtown Maryville (Arnold and Luce; Norris 1A, 6A). McCarthy likely had Kidwell in mind when he mentioned in a letter to Howard Woolmer, in February 1970, that "an artist friend" wanted to do illustrations for McCarthy's "forthcoming book"most likely Suttree. Kidwell had begun painting watercolors of Knoxville's downtown when he was a student studying art and psychology at the University of Tennessee (Pickle B1), and he created more during the time when he and McCarthy were neighbors. Kidwell's watercolors Henley Street Bridge, Knoxville Tennessee (1968) and Gay Street Bridge, Knoxville Tennessee (1969), for example, represent significant locales of Suttree consistent with its time setting and may be two of the illustrations projected for the novel.

9 This idea for plates was not realized when Suttree was published in 1979, but as McCarthy composed his next novel, Blood Meridian, his plan was to illustrate it with period artwork. In 1978 he mailed his editor at least two batches of plates for the novel. In a separate envelope he also sent an 1850 map of the border territory (Letter to Erskine, received 12 Sept. 1978). The next spring he wrote to Howard Woolmer that the new novel was "a western... illustrated with about 2 dozen period prints-woodcuts mostly" (postmarked 2 Feb. 1979), adding later that these were "from old books about the southwest" (Letter to Woolmer postmarked 27 Jan, 1981). 
10 The specific works he hoped to include remain somewhat conjectural since only the map was published in the novel ${ }^{5}$ and McCarthy's packets of illustrations survive neither in Erskine's nor in McCarthy's papers. His primary narrative source for the events surrounding Glanton's gang, Samuel Chamberlain's My Confession, had itself been illustrated with Chamberlain's watercolors and drawings, but these seem unlikely candidates for the woodcuts and lithographs that were to illustrate McCarthy's novel. However, in the margins of his unpaginated reading notes for Blood Meridian McCarthy inscribed the reminder "ILLUS" to flag some of the images he might include in the novel and/or to identify those that might inform his own visual imagery. He noted the "nice drawing of Jesus y Maria July 20 1849" in John Woodhouse Audubon's Western Journal, page 122. In Edward King's The Great South, page 161, he discovered J. Wells Champney's illustration of the military plaza in San Antonio, and the American Heritage volume Texas and the War with Mexico, page 58, provided a painting of San Antonio in 1849. James Hobbs's Wild Life in the Far West included a few illustrations but "not much" that suited his purposes; and his notes do not identify any specifically. But in McCarthy's earliest extant draft he noted in the margin of a Santa Cruz scene, "Plate J Ross Brown Adventures p. 190"-a reference to Brown's Adventures in the Apache Country ("First Draft" 306/ 302B; see BM 220). These notations suggest that many of the illustrations were to have been of the novel's towns and settlements rather than its wilderness scenes, but they do not provide enough information fully to reconstruct the list of two dozen plates McCarthy had hoped to reproduce. His other nineteenthcentury sources also included illustrations, such as the woodcuts and lithographs from boundary commissioner John Russell Bartlett's Personal Narrative or the sketches of $\mathrm{H}$. B. Möllhausen that illustrated The Whipple Report. Möllhausen's Fort Smith, Arkansas, and Bartlett's Quicksilver Mine, New Almaden (62), San Diego, California (95), Well at Alamo Mucho (134), Junction of the Gila and Colorado Rivers (158), Tucson, Sonora (292), Meteorite at Tucson (298), Janos, Chihuahua (340), and even Apache Indians Attacking the Train and Party (412) and Yucca Tree (491) were possibly among those he planned to reprint as illustrations for Blood Meridian.

11 McCarthy's involvement with art and artists has continued in the years since he completed Blood Meridian. It seems likely that his relationship with third wife Jennifer, an accomplished painter, included conversations about art. Several of her archetypal paintings employ the image of the she-wolf-an iconic image in McCarthy's novel The Crossing (1994) as well. In their respective art forms, both Cormac and Jennifer McCarthy responded to the 2001 terrorist attacks on American soil, creating works that embodied their mutual fears for their young son John Francis at a time when their marriage was troubled: Cormac in his intimate novel, The Road, and Jennifer in her room-sized outdoor sculpture Nest, which occupied McCarthy's front yard in Santa Fe at the time of Richard Woodward's second interview with him in 2005 (104). The sculpture expressed Jennifer McCarthy's maternal desire to protect the victims at the World Trade Center on 9/11. "The images of the people falling from the buildings reminded me of baby birds falling from the nests," she recalled. "I saw images of a giant mother catching them in her breast, and then a giant nest and then I thought of a giant nest to stand in place of the twin towers" ("Jennifer C McCarthy").

12 McCarthy's abiding interest in the visual arts is perhaps apparent too in his later affinity with artists and his willingness to sit for portraits. He met painter James Drake when both were living in El Paso, and their friendship continues in Santa Fe (Woodward 
104). ${ }^{6}$ McCarthy sat for Drake's City of Tells, 2002-2004, a composite charcoal portrait, mural-sized at twelve by thirty-two feet, and influenced in its conception by Raphael's The School of Athens (1509-1511; for reproductions, see Drake, 153-159). In this work, Drake aimed to "disclose something of his subjects..., a crowd of family, friends, and famous figures from history... opening their internal natures to our sight" (Madoff 19), and it is a testament to their friendship that McCarthy collaborated in the project.

Another drawing, done in 2005 when McCarthy's novel The Road was nearing publication, is Drake's City of Tells (Barca de Oro [Boat of Gold]) (see Drake, 167). This remarkable work depicts an older man seated facing a young boy, each smiling in enjoyment of the other. Christopher French, who may have interviewed Drake, identifies these figures as Drake and his grandfather. But the older man bears a notable resemblance to McCarthy, and the work may also be read as a portrait of the writer with his young son John Francis, a companion to the autobiographical portrait McCarthy himself presents in The Road. The man's right hand, holding a cigarette, and his left, resting forward over his knee, extend under the boy's two hands, which offer a small package tied with a simple bow. Their legs and feet blend into the wave-like forms at the bottom right of the drawing. At the lower left are two grotesque figures, one floating face up, his head lolling back under the man's right knee; the other, his face animated by anger, with his left shoulder against the man's back and raising the knuckles of his left fist to his grimacing mouth. French identifies these as reproductions of a drowned sailor from The Raft of the Medusa (1819) by Gericault and a doomed soul from The Barque of Dante (1822), also known as Dante and Virgil in Hell, by Delacroix. Above these contrasting pairs of figures floats an out-sized inverted head with blowing hair and wild eyes, open-mouthed with torment, based on Michelangelo's drawing Fury. French writes that "Ripped gashes in the paper course from top to bottom; exposing the paper's silvery canvas backing, they evoke the jumbled, incandescent atmospheres of memories or dreams." These tears slightly obscure all the figures except for the boy, whose innocent face occupies an amnion of light, a realm outside of the tumultuous darker imaginings of his doting father or grandfather. If one reads these figures as Cormac and John, the boy compensates for the hauntedness of McCarthy's creative life while coexisting with it. City of Tells (Barca de Oro) was included in Drake's 2006 solo exhibition titled Towards the Pandemonium of the Sun-a verbal homage to Blood Meridian (185), by which it was perhaps inspired, although Drake's works have also been compared with Dante and with Goya's Disasters of War series of etchings (1810-1820) - both of which McCarthy's work also alludes to.

Despite his usual shunning of publicity and his sometime reluctance to be photographed, in 2003 McCarthy allowed British portraitist Andrew Tift to make photographic studies of him for a series of twenty portraits of New Mexicans for a Santa Fe gallery. In his blog, Tift reports, "I think something just clicked between us and we seemed to get on." Working at home in England from his photographs of McCarthy, Tift completed his photorealistic acrylic-on-canvas portrait in 2004 and shipped it back to the gallery. In 2008, the Smithsonian purchased Tift's paintings of McCarthy and his friend physicist Murray Gell-Mann for the National Portrait Gallery, bringing McCarthy's own image into one of the museums he likely visited forty years earlier (Tift; Grimley, News sec. 13). In 2010-2011, these portraits were included in the gallery's "Americans Now" exhibition. 
15 Finally there is McCarthy's informed contribution to the discussion of prehistoric cave paintings in Ira Flatow's National Public Radio interview with McCarthy, physicist Lawrence Krauss, and Werner Herzog, director of the documentary, Cave of Forgotten Dreams: Humanity's Lost Masterpiece (2011). All these experiences demonstrate that although McCarthy did not develop his childhood artistic ability into a career, his interest in the creation, history, interpretation and enjoyment of art has been one of his many life-long pursuits. It would be surprising if that passion did not inform his literary works, in which visual imagery is so prominent a feature.

\section{The Language of Art and Allusions to Artworks in Blood Meridian}

16 The painterly sensibility of Blood Meridian's narrator appears explicitly in his use of artists' or art critics' diction. For example, pursued by Apaches, the gang rides across an open expanse where "To the east trembling in the heat stood the thin white walls of a hacienda and the trees thin and green and rigid rising from it like a scene viewed in a diorama" (164). Later, from their ground-level vantage point on the rim of the Alamo Mucho wells, the kid and Tobin spot the "figure" of the judge "in the middle distance" (294). In battles with Indians, violent action appears frozen in kinetic potential when dogs howl "in a tableau of some hellish hunt" or riders appear as "a thin frieze of mounted archers" $(155 ; 109)$. The Indians' ponies are so coated with dust that the painted emblems on them appear in palimpsest, "like the shade of old work through sizing on a canvas" (52). On a moonless night, lightning calls forth a sequence of dark mountain landscapes that shudder in their "clattering frames" as if they are literally framed and displayed against the dark wall of the night sky (187). One desert landscape is a "barren mural of sand and sky"-Rothko-like color-fields of blue and ecru (279). When the kid and Sproule climb under a wall of columnar basalt, the narrator sees the geological feature as a series of sculpted prophets (62).

17 The novel also occasionally alludes subtly to particular well-known artworks. In a moment of frozen action, the attacking Comanches, "a wild frieze of headlong horses with eyes walled and teeth cropped and naked riders" (53), evoke ancient Greek reliefs of horses and riders such as those that adorned the processional inner frieze of the Parthenon or its outer metopes of the battle between the Lapiths and the centaurs, a reminder of the long history of human engagement in war. McCarthy may have seen some of these relief sculptures in the British Museum in London or in the Louvre in Paris. In Nashville he likely saw the full-scale reproduction of the Parthenon, with its plaster casts of the British Museum friezes. Constructed of impermanent materials for the Tennessee Centennial Exposition in 1897 and rebuilt in 1920-1931, it existed in its current manifestation even before McCarthy's family moved to Tennessee in 1937 and was still there when McCarthy lived in Nashville in 1979.

18 Two scenes in Blood Meridian allude to works of the Spanish painter Pablo Picasso. The narrator describes a partly devoured mule carcass as "something from a chromo of terrific war" (119), an evocation of Picasso's color studies for the dismembered horse, bull and human figures in his mural Guernica (1937), an allusion that subtly imports Picasso's anti-war stance to Blood Meridian, where it reinforces the melancholia of McCarthy's narrator. In addition, McCarthy's note to himself-“mimetroupe / or mountebanks = (saltimbancos)"-in his "First Draft" (260) suggests that he thought of 
his family of traveling magicians dressed in "fools costumes... faded and pale from the dust of the road" (BM 89) in terms of Picasso's Family of Saltimbanques (1905). Indeed, McCarthy's description of the troupe loosely recalls this painting from Picasso's circus period, which McCarthy could have viewed in the National Gallery in 1968. Picasso's family of performers are more numerous than McCarthy's, and they are not bedecked in arcane symbols, but one man wears a harlequin costume (which figures in McCarthy's scene on the Tarot card of the fool), and an older man dresses as a clown. The woman, wrapped in a shawl, sits with her skirts tucked under her at a slight remove from the standing figures and with her back to them, a position mirrored by the fortune-teller of Blood Meridian (92). Picasso's troupe is foregrounded against a barren landscape that more resembles an abstracted western landscape than it does a street scene near Montmartre, where Picasso encountered such wandering performers.

McCarthy's description of Sproule's horror at being bitten by a vampire bat evokes Edvard Munch's expressionistic The Scream (1893): "he held out... his bloodied hands as if in accusation and then clapped them to his ears and cried out what it seemed he himself would not hear, a howl of such outrage as to stitch a caesura in the pulsebeat of the world" (66). Sproule's gesture is anticipated when the survivor of an Indian attack whom Glanton's men drag from his hiding place thrusts "his hands over his ears and his elbows before his eyes like one called upon to witness some appalling thing" (49). McCarthy may also have known of the autobiographical genesis of The Scream, which is expressed more directly in the painter's related images of his young sister's anguished reaction to their mother's death, The Dead Mother and Child (1897-1899) and Death and the Child (1899)-her attempt to shut out the event by pressing her hands over her ears. The Scream redeploys the gesture in a more generalized way, as an expression of existential angst. Interestingly, three of the four versions of Munch's The Scream are dominated by blood-red sunsets over the Oslo fjord, from which the figures seem to turn in horror, including his best-known rendition of 1893, at the National Gallery in Oslo.

Such fleeting allusions to artworks often function as visual analogues that import sensory and emotional perceptions from other realms of human culture to deepen and contextualize the reader's response to the novel's scenes of violence and to imply the narrator's own response. The scene at Alamo Mucho, more extended and nuanced, evokes and deconstructs Frederic Remington's Fight for the Waterhole (1903). This painting of the "last stand" (Hughes 205), depicts five armed Anglo-Americans spaced out on the rim of the crater, with jagged blue mountains in the far distance. Circling them on the vast yellow color-field of the desert plain are tiny figures of Native American riders. Dwarfed though they are within the broad landscape, their presence signals impending doom for these particular Anglo-Americans, even while, with early twentieth-century hindsight, the painting also implies the closing of the west and the reciprocal hemming in of Native Americans. McCarthy's "Alamo Mucho" scene begins with a reinscription of Fight for the Waterhole: "The pit in which the well was sunk was perhaps a dozen feet in diameter and they posted themselves about the inner slope of this salient and watched while the Indians fanned out over the plain, moving past in the distance at a slow lope" in the "heat shimmering off the pan in the late sunlight" (279; 281). McCarthy places the three survivors of the Yuma Crossing massacreToadvine, Tobin, and the kid-in the desert well, and by evoking Remington's painting of the last stand he augments the reader's dread for their fate. But despite their vulnerable position, McCarthy makes his trio survivors of this attack as well. Instead of 
the Yumas, who in their retreat from the kid's dead-eye gunfire appear "very small indeed" (280), he posits the judge as the looming presence that threatens the Americans' ultimate defeat from within. Then, in McCarthy's ironic reversal of Remington's implied narrative, pacific Diegueños rescue the men from the desert where they have fled the judge (300).

21 Sometimes the narrator's references to artistic genres implicitly critique American myths of the west. He invokes nineteenth-century traditions of Indian portraiture when he describes dispossessed Tonkawa Indians framed in the windows of the Fort Griffin saloon, "composed in strange lost portraits" (333). McCarthy rarely describes characters' facial features, and although his narrator does not here limn visual portraits of individual lost Indians, one thinks of the classically-influenced portraits of Native American delegates to Washington done by Charles Bird King for the Bureau of Indian Affairs (Hughes 176) or Karl Bodmer's more ethnographically authentic watercolors of Mandans, painted when he served as the artist for Maximilian zu Wied's 1833-34 expedition up the Missouri (Hughes 180). Painters of the Comanche included George Catlin, who accompanied Colonel Henry Dodge's expedition, and Henry H. Cross, who lived among various Native Americans (Broder 16-17; 58-59). Recent art historians argue that these portraitists were motivated by a desire to collect the faces and cultural artifacts of a people they and the rest of the nation assumed were destined for extinction, and they debate how exploitative their work was. In the aftermath of the Indian fighters' campaigns, the narrator's reference to the Tonkawas as impotent remnants framed outside the rowdy saloon, a manifestation of the coarser aspects of American culture, suggests his skepticism about the United States' programmatic replacement of the Indians' culture with Euro-American commercialism and progressivism. His allusion to Indian portraiture recalls the judge's capturing Native American and Spanish artifacts in his sketchbook and then destroying them (139-140). And the narrator's attention to these artifacts, as well as to the decorative arts applied to the rifle David Brown mutilates (265-266), the ruined Catholic churches and missions of the southwest, and the Penitente sect's carved images of La Muerte (see Luce, "Death Carts"), reveals his appreciation of the artistic endeavors of the various cultures represented in the book.

In his descriptions of crimson suns, McCarthy alludes to nineteenth-century American sunset paintings that contributed to the nation's sense of identity by glorifying its western landscape. However, McCarthy repeatedly links the sun with cosmic threat, calamity, and bloodshed, as in the passages "the sun in the east flushed... a deeper run of color like blood... and... the top of the sun rose out of nothing like the head of a great red phallus until it cleared the unseen rim and sat squat and pulsing and malevolent behind them" (44-45), or "They eyed the sun in its circus and at dusk they rode out upon the cooling plain where the western sky was the color of blood" (152), or "in the long red sunset the sheets of water on the plain below them lay like tidepools of primal blood" (187). In Blood Meridian, the sun on the western horizon deconstructs the sublime beauty and heroic aura of Alfred Bierstadt's many sunset landscapes, Thomas Moran's restless Pacific Sunset (1907), and Frederic Church's North and South American landscapes suffused with crimson light, such as Twilight in the Wilderness (1860) or Cotopaxi (1862). Jarrett insightfully comments that McCarthy's Southwestern landscapes "part company with Church in resisting [the] national myth of historic progression from nature to civilized dominion over nature, implying that such progression is an interpretive projection and illusion" (139). And McCarthy's subtitle, The Evening Redness 
in the West, specifically reinscribes Church's title, Twilight in the Wilderness. Barbara Novak writes of this painting: "The flame-like shapes, their reflections suffusing the stilled landscape below, enact a baroque ecstasy in the heavens. Church often presented a transcendent Deity through this apocalyptic majesty" (98). But McCarthy's twentieth-century evocations of the blood-red western sky disallow any comforting illusion of a benevolent Deity's blessing on the American enterprise and invoke instead the bloody course of empire and post-meridian decline. Indeed, with their apocalyptic glow, American painters' western sunsets of the 1860s and 1870s are susceptible to ironic or pessimistic interpretations. Consider, for example, Church's Our Banner in the Sky (1861) with its tattered stars and stripes composed of the clouds at sunset, a work which may have been meant as Unionist rhetoric, but which can alternatively be read, like McCarthy's post-Vietnam-era novel, as a warning against American militarism.

Such deployment of art terminology and references to specific artworks and traditions alert the reader to the presence of the narrator's own painterly constructions. Indeed, one structuring device in Blood Meridian is a rhythm of landscape scenes providing moments of stillness, contemplation, or aestheticizing distance in tension with the violence and kinetic energy that otherwise pattern the novel. For their duration, such landscapes are focalized from a static vantage point while the narrator's eyes move over the elements of the scene. Some include the still figure of Glanton, the judge, or the kid gazing over the vista, and others place the viewer/reader in an elevated position to consider the gang moving across the landscape in a distant middle ground. Many landscape compositions emphasize the geological or ecological features of the land, often tempering the naturalist's perspective with a melancholy expressionism that defamiliarizes the terrain, reviving for the reader the sense of the uncanny with which the land struck the early explorers of the west. Always these concentrated landscape passages also function as prose poems, conjoining visual imagery with other poetic resources of language.

Thus the novel's landscapes often constitute an oblique form of narrative commentary on the mindless venture of the gang and on America's pursuit of Manifest Destiny. They invite us to pause in our headlong following of the novel's plot of pursuit and flight and to observe with the narrator from a removed, sometimes even cosmic position that invites ethical and metaphysical considerations. Often bathed in the iconic light of sunrise, sunset or deep night, or briefly illuminated by flashes of lightning, the scenes suggest both scientific and Manichaean determinisms that apparently direct the actors in the unfolding drama. McCarthy's landscapes here are not the renderings of the pastoral or picturesque or even the sublime west distributed to curious nineteenthcentury Americans in the cultural centers back east. Rather, they tend to deconstruct and de-romanticize the mid-nineteenth-century west and the imperialism that claimed, tamed and absorbed it as part of America.

\section{3. "Under the Animas peaks"}

Conventionally formatted art-titles in the chapter headings of Blood Meridian underline the painterly status of several of the most fully articulated landscape scenes in the novel, a tactic which prompts the reader to ponder the spatial composition and visual imagery of these titled scenes, and by extension the "untitled" vistas as well: to read them slowly for their iconographic and metaphorical implications as one would a 
painting. An early example is the scene entitled "Under the Animas peaks" (100)-a vista revealed as the gang emerges from the mountains to gaze over the terrain from the high vantage point of a mesa. The narrator's eyes range over this landscape from background to foreground to middle ground and from west to east as if the view were focalized through the gang, who must orient themselves in unfamiliar terrain and scan it efficiently for the Indians they seek and fear. But the narrator's interpretation of the landscape transcends the gang's pragmatic view (indeed in his reading the men temporarily disappear from our view). As composed by the narrator, the scene constitutes a reading of the American west as a realm of illusory beauty grounded in violence:

The sun to the west lay in a holocaust where there rose a steady column of small desert bats and to the north along the trembling perimeter of the world dust was blowing down the void like the smoke of distant armies. The crumpled butcherpaper mountains lay in sharp shadowfold under the long blue dusk and in the middle distance the glazed bed of a dry lake lay shimmering like the mare imbrium and herds of deer were moving north in the last of the twilight, harried over the plain by wolves who were themselves the color of the desert floor. (105)

This verbal landscape refers to humanity's bloody history and predicts the particular bloodshed to come the next morning, when Black Jackson murders White Jackson and Apaches attack the gang (107). It employs diction-holocaust, void, mare imbriumunavailable to Glanton, through whom the scene initially appears to be focalized. That is, the landscape is not Glanton's vision but the narrator's. In its etymology the "holocaust" visible in the west suggests that as the sun descends to the horizon, it ignites the world in its entirety: that it is wholly burnt. Further, the association of the word with World War II ethnic massacre overlays this image of the American west with an evocation of the furnaces in the concentration camps, and the dark bats backlit by the blazing sunset suggest both the smoke from those incinerators and the rising souls (or animas) of the victims. The emotional valence of such an image is far from neutral, either in its linking of the gang's genocidal aggression with that of Nazi Germany or in its suggestion that such violent ventures in human history transform the world to a scorched earth, a "void" that "tremble[s]" in the smoky, dusty aftermath of the clashing of "distant armies." The dust may be a trace of the Indians, but McCarthy's diction also imports the imagery and some of the tone of Matthew Arnold's "Dover Beach," in which the poem's speaker soberly imagines both the misery of earlier epochs and the modern human condition:

we are here as on a darkling plain

Swept with confused alarms of struggle and flight,

Where ignorant armies clash by night. (11. 35-37) ${ }^{7}$

The apocalyptic horror of this landscape's western rim, an image of "the evening redness in the west," seems slightly relieved when the narrator's eye moves on to the stark mineral formations of the Animas Mountains and the cooler-toned middle ground, the playa that glitters like overlapping waves (the "mare imbrium") in the blue dusk. But the mountains' bare geological formations remind the narrator of "butcherpaper" and thus allude to humankind's predatory nature. And the shimmering lake proves a mirage, an illusion created by the low sun that glazes the surface of the dry lake bed, an example of "the will to deceive that is in things luminous" (120). The deception is extended when the narrator notes the passage of deer across the plain, often emblematic of pacific and benign unspoiled western American wilderness, as in Albert Bierstadt's formula of deer in the foreground of a lake with majestic mountains 
in the background (see for example Valley of the Yosemite [1864], Among the Sierra Nevada, California [1868], or Sierra Nevada Morning [1870]). Patricia Broder writes that in these paintings "The deer frolicking on the edge of the lake are symbolic of the peace, innocence, and tranquillity [sic] of nature, untouched by man" (74). But in McCarthy's scene, the transient illusion of peaceful beauty is abruptly dispelled by the recognition that the deer neither play nor graze but are "harried" by wolves camouflaged against the desert playa. This is a deceptive and predatory landscape, a terrain of cosmic, natural, and human violence; and the narrator's sober vision implies that the beauty of the world is a mirage that obscures its dark nature.

The next paragraph returns Glanton to the foreground as a viewer of the land and thus potentially the narrator's and the reader's surrogate: "Glanton sat his horse and looked long out upon this scene" (105). But the narrator forestalls any identification with Glanton. In landscape painting, the figure in the landscape typically represents the human relationship to nature, whether absent from it, dwarfed by it, pondering its grandeur, or dominating it (see Novak 184-200), and Glanton's vigilant and hostile gaze throughout the novel exemplifies the "imperial" or "magisterial" gaze that art historians find in some nineteenth-century American artworks: the figure who, rather than being absorbed by a landscape in a harmonious, even spiritual symbiosis with nature, regards the wilderness from a domineering position in preparation for invading and appropriating it (see, for example, Albert Boime's The Magisterial Gaze [1991] and Angela Miller's The Empire of the Eye [1993]). In effect, such a figure becomes the machine in the garden, the eruption of destructive aspects of human culture in the pastoral realm or, in this case, the wilderness. The passage depicting Glanton on the promontory extends the military imagery of the previous paragraph: "Sparse on the mesa the dry weeds lashed in the wind like the earth's long echo of lance and spear in old encounters forever unrecorded." But this perception too is the narrator's judgment of the figure of Glanton in the landscape, not Glanton's perception of the landscape before him, and it emphasizes Glanton's / humanity's enduring dedication to war and imperialism. The paragraph ends with the narrator's dire prediction for Glanton, his men, and all human endeavors: "He passed and so passed all into the problematic destruction of darkness" (105). The narrator does more than objectively perceive and record such landscapes; he composes and interprets them, enacting the process of "reading" landscape as landscape painting: performing the functions of both artist and viewer. The narrator brings to his visual perceptions of the scene his knowledge not only of American and European traditions of landscape art, but also his imaginative engagement with poetry and history.

\section{4. "Ice and lightning"}

Another landscape title, "Ice and lightning" (151), applies to two paired brief and almost static painterly images of the gang moving at night across the desert, images that illustrate the narrator's melancholy brooding on the nature of their venture:

they traveled under the cape of the wild mountains upon a broad soda plain with dry thunder to the south and rumors of light. Under a gibbous moon horse and rider spanceled to their shadows on the snowblue ground and in each flare of lightning as the storm advanced those selfsame forms rearing with a terrible redundancy behind them like some third aspect of their presence hammered out black and wild upon the naked grounds. (151-152) 
The narrator positions us at considerable distance from the riders: our view takes in the entire retinue, the barren, luminous soda plain on which they travel, the mountains beyond them and the moon above. As in so many of these painterly scenes, light and shadow receive emphasis. However, contrasting with the novel's insistent images of the men under a blood-red sun, the palette here is cool. Despite the title of the passage, no ice appears in the scene (although hail falls the next night), but the waxing moonlight on the plain makes of it a "snowblue ground" or pale scrim against which the men's shadows reproduce their forms in darkness. Not only the horses but the riders too seem hobbled to their shadows, their darker selves. In the narrator's metaphor, their own darkness is the agency that restricts their freedom.

This ominous image quickly gives way to a pendant painting of the same scene now illuminated by the lightning of a distant but approaching storm. Here the narrator's interpretation becomes even more explicit and affective, as the riders' "selfsame forms," their shadows, loom larger and yet darker under the intermittent flashes of light. The narrator finds this reinscription of their shadows a "terrible redundancy" as the moon-shadows below the riders that appeared to hobble their movement are replaced by lightning-forged shadows arising behind them to reveal something truer and more disturbing still. As alternative figurings of their forms, the pursuing shadows are a "third aspect" of their nature, "hammered out" by a Vulcan-like creator or demiurge. Flickering into being, the "black and wild" shapes that image forth the emerging nature of the men do not restrict them in their motion as the paler moonengendered shadows appeared to do, but stalk the men and drive them on, perhaps to their doom. Building on the implications of these paired painterly landscapes, the narrator observes that it is as if the men were "invested with a purpose whose origins were antecedent to them, like blood legatees of an order both imperative and remote"-doomed to act out their ancient hereditary, predatory nature (152).

\section{5. "Night scene with moon, blossoms, judge"}

The narrator's gaze lingers over the judge as well, often isolating him as a lone monstrous figure against a landscape. "Night scene with moon, blossoms, judge" (136) exhibits a distinctly painterly composition although it encompasses a certain amount of narrative movement and progression through time:

\footnotetext{
A lobeshaped moon rose over the black shapes of the mountains dimming out the eastern stars and along the nearby ridge the white blooms of flowering yuccas moved in the wind and in the night bats came from some nether part of the world to stand on leather wings like dark satanic hummingbirds and feed at the mouths of those flowers. Farther along the ridge and slightly elevated on a ledge of sandstone squatted the judge, pale and naked. He raised his hand and the bats flared in confusion and then he lowered it and sat as before and soon they were feeding again. (148)
}

As in "Ice and lightning" the scene is arranged in three visible planes, the ridge with judge and yucca in the foreground, the opaque mountains in the distance, and the lighter plane of the night sky and cerebral moon in the farthest background. A conjectural fourth plane, a middle ground inferred but not visible from the narrator/ viewer's vantage point, is the void beyond the ridge-a mysterious unseen abyss. Thus the scene is comprised of planes of geophysical grounding in the ridge and the mountains, alternating with the unplumbed spaces of the lower void and the upper 
ether. As in other depictions of the judge, where he postures atop a wall or battlement or on the rim of a volcano in naked display of his nature, he is here positioned on the brink of an abyss which he does not perceive as a threat.

A study in darkness and luminosity against the layered planes, the scene organizes a pyramid of pale curved shapes of differing scales-lobed moon, yucca blossoms, and naked judge. The figure of the squatting judge looms most palpably, but it structurally balances the yuccas on the opposite side of the composition. In the rounding of his pale form and his bald dome, the judge echoes the shape of the luminous moon, which suggests an affinity between them and recalls the ancient gnostics' sense that heavenly bodies were aspects of the oppressive world rule of the archons, which monitored cosmic life and subjected both humans and nature to heimarmene or necessity.

Despite McCarthy's acute ecological awareness elsewhere, in this scene he notably undermines certain conventions of the naturalist's art. Although bats feed on the fruit and pollen of yucca plants, suggesting the biotic associations typical of a painter such as John James Audubon, particular plant and animal varieties are not identified here. It is tempting to visualize the yucca as the tall, sculptural Joshua tree (Yucca brevifolia), with arm-like branches that seemed to the Mormons to beckon them west. The Joshua tree is commonly photographed strikingly backlit by sunset or twilight and with the moon behind it, as in Ansel Adams' Joshua Trees, Rocks, Moon (c. 1948). But these forms may just as easily be another white-flowering desert yucca. In the same paragraph, but a few days earlier in their travels through the mesas, the gang has come across "strange forests of maguey-the aloe or century plant-with immense flowering stalks that rose forty feet into the desert air" (147). But the century plant, actually in the agave genus (Agave americana), produces a yellow flower rather than the white insisted upon in the narrator's landscape composition. McCarthy's uncharacteristic lack of specificity about his yucca species emphasizes iconography over realistic ecology and underlines the expressionistic quality of the scene.

Even the sense that the bats should be a pollen-eating species is tempered both by our earlier encounter with the carnivorous vampire bat that feeds at the throat of Sproule (66) and by the narrator's impression that the bats originate in some netherworld. Do these "dark satanic hummingbirds" sip nectar at the mouths of the blossoms, or do they feed on the pallid moths that pollinate the yucca? Either way, the ambiguity and the juxtaposition of dark bats with white blossoms evoke a "design of darkness to appall"-an insistent variation on Robert Frost's fat white spider grasping a dead white moth on a pale "innocent heal-all" blossom in a visual scene that provokes that poem's speaker to ponder what cynical power has orchestrated such a conjunction ("Design," 1l. 13, 10). In Blood Meridian, the most appalling whiteness belongs not, of course, to the bats, nor to the innocent yucca blossoms, but to the naked judge, whose imperial gaze takes in this scene with the satisfaction of possession, and who conducts the small drama before him-the flaring and resettling of the feeding bats-with a casual wave of his hand. The scene stands as a visual warning of the nature of the judge and of the Manichaean world of which he is, among other things, the demiurge-a world-ruler ignorant of Spirit, the very embodiment of materialism, empiricism, imperialism, Manifest Destiny, war, and death. 


\section{6. "Blood and mercury"} through fluids. Driven out of Jesús María, hung-over, enraged at the citizens and following the deranged Glanton, the gang meets a conducta of men and mules transporting mercury to the mines along a narrow mountain trail. There they fire on the muleteers and wantonly crowd the caravan over the precipice:

the animals dropping silently as martyrs, turning sedately in the empty air and exploding on the rocks below in startling bursts of blood and silver as the flasks broke open and the mercury loomed wobbling in the air in great sheets and lobes and small trembling satellites and all its forms grouping below and racing in the stone arroyos like the imbreachment of some ultimate alchemic work decocted from out the secret dark of the earth's heart, the fleeing stag of the ancients fugitive on the mountainside and bright and quick in the dry path of the storm channels and shaping out the sockets in the rock and hurrying from ledge to ledge down the slope shimmering and deft as eels. (195)

Although the scene clearly derives in part from John Russell Bartlett's period engraving, Quicksilver Mine, New Almaden (1852), McCarthy's treatment transcends Bartlett's documentary purpose, highlighting the imperial motives behind the explorer expeditions and the Glanton gang's and transforming the scene through allusions to alchemy and mythological metamorphosis.

narration positions us to overlook the abyss, the "empty air" opening out below us in a vertiginous void, initially making us complicit in the viewpoint of the murderers. Far from realistic, the scene represses the cries and even the bodies of the falling men to focus on the abject silence of the plummeting mules, augmenting the peculiar horror of the tableau. At the same time, the deaths of the men and mules are objectified and visually abstracted. Their "exploding" bodies are "flasks" that break open to spray their contents over the land, and death is conveyed indirectly through the brilliantly contrasting and mingling color forms-blood-red and mercury-silver-as the narrator averts his gaze from the broken bodies themselves. The scene's title reinforces this visual linking of the two fluids, one the substance of life, the other mineral, and thus obliquely critiques the acts of the gang for whom humans and animals become mere casks of liquid. For the reader/viewer, too, the sere earth becomes a canvas to accept the falling fluids as in the production of a Jackson Pollock drip painting using aluminum paint, ${ }^{8}$ a strange momentary flattening of the steep plane of the abyss and a dissociation of the vermilion and silver "paints" from all realistic or ethical content.

At this moment in reading the landscape, the narrator's (and reader's) vision fuses uncomfortably with Glanton's, who has orchestrated this scene partly to reenact his own bloody aesthetic, prompted by a recent vignette in which he has witnessed the plunge of one of his packmules into the "adamantine deep" under a "perfect china sky" (147). Glanton is a voyeur of violence, finding perverse beauty in the play and movement of color against a contrasting ground, yet insensitive to or excited by the pain and death inflicted on other beings. But although the narrator briefly apprehends Glanton's amoral visual aesthetic, he neither sustains nor endorses it. In further strange elision, as the narrator struggles to accommodate his horrific vision that reluctantly comprehends the burst bodies of the men and mules even as they are repressed, the blood is quickly displaced by the quick-silver, its movement suggesting an animation, a quick-ness outlasting that of blood. Indeed, the blood is alchemically 
transformed into the volatile mercury, which seems to leap from the earth in some "ultimate" fulfillment of the alchemist's hope to animate base minerals. The downward flux and upward eruption of the mercury counter the flattened perspective of the crimson and silver drip painting and reestablish the topography of the steep terrain. Both lava-like and enlivened, the mercurial forms collect and rush down the mountainside before undergoing metamorphosis in the narrator's eye first into the "fleeing stag of the ancients" and then into "shimmering" eels. Catching light like water in a conventional painting, these quicksilver forms define the contours of the land as if they were invisible but for the movement of animated, bright matter over them. The eye follows these morphing, diminishing forms ever deeper into the chasm until they elude it. The scene again enacts the narrator's warning against deception in things luminous, as the racing quick-silver diverts the eye from the spilled blood and the splattered bodies and visually leads us into the abyss.

41 As the narrator constructs his visual composition, he evokes both alchemy and classical iconography to comment on the murders. McCarthy initially drafted the reference to the stag as "the very soul of Azoth, the fleeing stag of the ancients" ("First Draft" 268). "Azoth" is another name for mercury in alchemy and the "fleeing stag of the ancients" is the Fugitive Stag (cervus fugitivus), a designation for mercury in alchemical writing, one which alludes to its mutability and its aspects as an elusive spirit of transmutation and even as the primal water of Creation (Haeffner 171-172), but also to its deceptive quality (Peterson 410).

At the same time, the fleeing stag also recalls Actaeon the hunter, whom the goddess Artemis or Diana transformed into a buck, and who was then pursued and torn apart by his own hounds. Artists of the classical scene have found interest both in the moment of Actaeon's voyeuristic transgression, as in Titian's Diana and Actaeon (1556-1559), and in his flight from his hounds, as in Titian's The Death of Actaeon (1559-1575), Francesco Zuccarrelli's The Hunting of Actaeon by Diana (pre-1762), and Paul Manship's sleek, dynamic gilt bronze castings of Actaeon (1925), one of which McCarthy could have seen in the Smithsonian American Art Museum. The narrator's metaphor ambiguously suggests in the elusive mercury a sense of its horror at both the violence and the voyeurism Glanton enacts, from which it flees, thus obliquely figuring the murderous gang simultaneously as transgressors, hunters, and hounds. The Actaeon allusion reinforces the motif of the hunter hunted that becomes increasingly evident in the last half of the novel and that characterizes the life of the kid after the massacre at the Yuma crossing. Indeed, Actaeon's fate, dismembered by his hounds, may well foreshadow the protagonist's in his final encounter with the judge in the jakes.

The alchemical and mythological associations remind us too that the Roman god Mercury was an avatar of the Greek Hermes, among whose various attributes were that he was god of thieves, commerce, and road travelers. As the messenger god, one of his roles was to conduct the dead to Hades, and thus the fleet mercury that rushes down the abyss alludes to the souls of the murdered muleteers. It also constitutes a narrative prediction of the gang's ultimate fate and suggests the sterility of their enterprise. In his Mercury/Hermes reference, the narrator figures the arid western landscape as the brink of the underworld; in the Actaeon image, he figures it as Mount Cithaeron, the wilderness site of bloody Bacchanalian rites in Greek mythology, usually painted with lush vegetation in European art. These apparently contradictory allusions to Greek mythology and topography co-exist in the narrator's reading of the visual scene and 
enrich its complexity at the same time as they partially insulate him and the reader from the pathos of the men and mules forced into the abyss, the grisliness of their burst bodies. Neither a celebration of violence nor a simple, sensational depiction of the horrors of war, the narrator's mercurial and morphing reading/painting of the scene of blood and mercury performs multi-faceted meditation on the gang's murderous acts.

\section{7. "The ocean" and "The sea"}

Contrasting scenes on the Pacific coast illustrate especially well the differences between visual imagery that functions primarily to unfold action, setting, or character, and painterly imagery that slows the pace and reveals the narrator's ethical and metaphysical meditation within the tale he is telling. The scenes are both set in San Diego and have similar titles, "The ocean" (260) and "The sea" (295), emphasizing their relatedness; but they are focalized respectively through David Brown and the kid. The chapter in which Brown sees the ocean is largely devoted to his trip to acquire supplies, and it stands as the only extended treatment of Brown acting separately from Glanton and Holden. Brown's choices in San Diego-his intimidation of the farrier, his mutilation of the beautifully crafted shotgun, his drunken murder of a soldier, his bribing and murdering the young guard Petit-all reveal how fully Brown remains tethered to the ethos of the gang. Brown's brief look at the ocean is of a piece with his experience in the rest of this chapter; indeed it parallels the pragmatic mode of perception he applies to the shotgun, devoid of aesthetic appreciation. He walks to the beach with Webster and Toadvine, all drinking from Brown's bottle: "They'd none of them seen an ocean before. Brown walked down and held his hand to the sheet of spume that ran up the dark sand. He lifted his hand and tasted the salt on his fingers and he looked downcoast and up and then they went back up the beach toward the town" (268). Brown's gaze is exclusively sensory and materialistic: he regards, touches, and tastes the water in rapid succession; then he is done with it. This encounter with the unknown prompts in him no lingering awareness, no deeper level of perception.

The second of these paired scenes, "The sea" subtly establishes the ways in which the kid, although he has allowed himself to be absorbed into the gang, is capable of more sensitive perceptions even though he does not and perhaps cannot articulate them and though his awareness is far more limited than the narrator's. With deeper curiosity and intentionality than Brown, he seeks the coastline even before finding a doctor for his wounds, and he gazes long at the seascape, watching until the sun has set and little is left to see. These details suggest in the kid a certain intensity of vision, his reading of the sea emotionally if not intellectually.

The encounter begins with visual details of the scene, often expressed in the noun fragments that McCarthy frequently employs for a character's sequentially perceived visual images. The passage represents the kid's eye as it moves over the vista noting what is there and mimics the viewer's eye as it absorbs the elements of a painting before interpreting. These isolated images gradually give way as the narrator's voice becomes more dominant and performs a contemplative reading of the scene and of the kid in the scene that transcends the kid's perspective:

Loose strands of ambercolored kelp lay in a rubbery wrack at the tideline. A dead seal. Beyond the inner bay part of a reef in a thin line like something foundered 
there on which the sea was teething. He squatted in the sand and watched the sun on the hammered face of the water. Out there island clouds emplaned upon a salmoncolored othersea. Seafowl in silhouette. Downshore the dull surf boomed. There was a horse standing there staring out upon the darkening waters and a young colt that cavorted and trotted off and came back. (303-304)

We take in the scene progressively, from the detritus in the foreground to the reef in the middle ground, then the sun, sea, clouds and birds in the distance, before noticing the sound of the surf downshore and returning visually to the shoreline and the unexpected mare and her foal. The planar organization of the seascape suggests the strategies of the American luminist painters of the nineteenth century, who rendered foreground in realistic detail and through their handling of light suggested the transcendental in the distance. But McCarthy's rendering of the scene, while no less meditative than the luminists' Atlantic seascapes, is far less tranquil. It may have been partly suggested by such a painting of the Pacific shore as Bierstadt's austere Sunset on the Coast (1866), with its intense setting sun emanating light over the water to illuminate the coastal rocks, whose shadows project towards the viewer. However, the kid's initial perceptions of the coastline are far from sublime, with their details of death and destruction in the fore- and middle ground. He does not discern what is "foundered" on the reef, but the "wrack" of seaweed-a near-homophone of "wreck" which sometimes carries the same denotation-conveys the narrator's impression of a shipwreck there, with all its connotations of the failure of individual or national endeavor and its sense of the aftermath of things. ${ }^{9}$ This foundered thing, then, functions as narrative commentary on the disastrous outcome of the Glanton gang's venture as Indian-fighters and murderers, introducing a vanitas motif without suggesting that the kid connects the conjectural wreck with his own past or futureindeed that he even sees the foundered thing as a shipwreck.

As a prose poem, "The sea" relies even more than other landscapes on linguistic associations that escape the semantic boundaries of the sentences. The word "foundered" is joined by "hammered" in the next sentence to evoke a sense of the sea as a creation, a thing hammered out in the foundry of some Vulcan-like god. Consistent with its relentless role in the novel, the sun is the agent that hammers out the sea like copper. Yet the world's capacity to delight is insisted on in the brilliant copper face of the sea, and the "salmoncolored othersea" of the sky, sublime images that take us from the ugly realism of the sea-wrack and the dead seal to the ethereal. Indeed, the dramatic beauty of the setting sun backlighting the flying seabirds seems to motivate the kid to sit and watch. For him, it is a renewed experience of the beauty of the world; for the narrator and the reader, it is also a witnessing of the apocalyptic evening redness in the west, an allusion to the bloody course of Manifest Destiny halted only-if at all-at the Pacific Ocean, which "teeths" on the wreck of human enterprises.

With the appearance of the horse and her colt, several interesting things transpire. First, she is a mare, la mer, and thus through this homophone she is an "othersea" herself, a linguistic sleight that posits a unity of the natural world-creature and sea and sky-which complicates the earlier suggestion that the cosmos is Manichaean in origin. She is further linked with the sea through the animation of its "black hide" and the loping of its waves on the shore (304). Her foal frisks in the surf, but she stands looking out to sea, another viewer in the scene, one whose presence suggests other ways of looking. She is the kind of figure Novak finds most intriguing in American landscape paintings, "the single figure, engaged in some sort of meditative dialogue 
with nature" (190). Moreover, she is a rare instance of the maternal in this novel in which human children are denied the protective maternal embrace. Her presence reminds the reader and perhaps the kid too of the absence of a mother in his life; and the colt absorbed in his play instead of sober observation of the ocean becomes a more innocent figuring of the kid in his earlier, thoughtless self-expression through the "play" of mindless violence and war.

As a stand-in for the narrator/viewer and thus for the reader, the mare gazing out to sea is a figure contemplating mystery. Rather than the kid, who looks but whose capacity for vision is limited, she becomes the still, lone figure in this seascape, a figure who evokes a long painterly tradition in which looking from land's end to sea, especially at sunset, represents a profound encounter with the unknown, with the infinite, and with one's own limitations and mortality. The attentive mare of "The sea" recalls but contrasts significantly with Bierstadt's White Horse in the Sunset (c. 1863), in which a pale horse occupies the foreground and is backlit by the last rim of light in the west. Behind the horse lies a dark band of water, from which the horse looks inland. Bierstadt's juxtaposition of this icon of the American west with the coast and sunset suggests the limits of empire. His horse is a dull, exhausted creature, functioning in much the way a shipwreck does to suggest profound aftermath. In contrast, McCarthy's vital, observant mare is the narrator's and our proxy, through whom we ponder the Pacific at sunset and the enterprise which has led the kid and the American nation to this point.

51 The narrator infers that the focus of the mare's gaze is the whales who "ferry their vast souls" through the sea (304). "Ferry" of course recalls the disaster of the Yuma ferry, the culmination of the gang's bloody history. But the whales exist in a realm unknown to the Anglo-American men like Glanton's gang who pursue suzerainty to the western limits of the land, to the ultimate barrier of the ocean. In the narrator's construction, the whales ferry not merely their corporeal beings but their souls, suggesting that their agency is more spiritually attuned than that of the men whose fates he has delineated throughout the novel. He interprets both the horse and the whale-iconic creatures in McCarthy's All the Pretty Horses and his unpublished screenplay "Whales and Men," respectively-as creatures who embody and exemplify his own sense of the mystery of the world. Except for the epilogue's man who strikes fire out of the rock, they are the most affirmative figures in this novel, conveying the narrator's sense of alternatives to blood and conflict. The mare's steady gaze is neither predatory nor imperial but suggests an openness to the whale's otherness-its vast soul. Yet the seascape also carries the narrator's melancholy recognition that the whale itself is hunted and the ocean is the stage for another form of manifest destiny, where nineteenth-century American whalers slaughtered right and sperm whales for their oil, just as AngloAmerican hunters made vast bonefields of the Great Plains where once the buffalo roamed. The sea is a barrier that turns back both Brown and the kid. It marks a limit to their suzerainty. It is the realm of mystery. Yet it too is a contested realm, a killing field Americans have sought to dominate.

In his narrative deployment of painterly techniques in Blood Meridian, McCarthy invites slow reading, full engagement of the mind's eye together with our intellectual resources and perceptions. What McCarthy's titled landscapes share besides their status as complex prose poems is their function as the narrator's sober meditations on the violence of war and Manifest Destiny. While the novel's many scenes of violent 
conflict can and should be read as McCarthy's critique of humankind's eternal propensity for aggression, rather like Picasso's Guernica or Goya's Disasters of War series, these scenes have also been read by some as celebrations of violence. McCarthy's landscape scenes, however, critique war in a less ambiguous manner, by evoking in the reader a mode of perception analogous to that of the thoughtful and culturally literate viewer of a painted landscape, by teaching us to read the landscape as the narrator does. These tableaus are far richer than conventional novelistic passages of setting or scenery: in their complex arrangements of iconography, their deployment of light, shadow and color, the narrator's allusions to the traditions and compositional techniques of landscapists and other painters, including painterly allusiveness to myth and literature through iconography, and their conjunction with the poetic resources of language, they express the narrator's deeply troubled apprehension of the unregenerate violence of human nature. In such scenes, the narrator positions the reader with himself as a gazer into the abyss that is humanity, that may be humanity's fate.

\section{BIBLIOGRAPHY}

Albert Erskine Random House Editorial Files, 1933-1993. Accession \# 13497. Special Collections, U of Virginia Lib., Charlotttesville.

Arnold, Edwin T., and Dianne C. Luce. Unpublished interview with Bill Kidwell. Maryville, TN. 5 Aug. 2000.

Arnold, Matthew. "Dover Beach.” The Poems of Matthew Arnold. Ed. Kenneth Allott. London: Longmans, 1965. 239-243. Print.

Audubon, John Woodhouse. Audubon's Western Journal, 1849-1850. Cleveland: Arthur H. Clark, 1906. Print.

Bartlett, John Russell. Personal Narrative of Explorations and Incidents in Texas, New Mexico, California, Sonora, and Chihuahua Connected with the United States and Mexico Boundary Commission During the Years 1850, '51, '52, and '53. 2 vols. in one. New York: Appleton, 1954. Print.

Boime, Albert. The Magisterial Gaze: Manifest Destiny and American Landscape Painting c. 1830-1865. Washington, D. C.: Smithsonian Institution P, 1991. Print.

Broder, Patricia Janis. Great Paintings of the Old American West. New York: Abbeville P, 1979. Print.

Brown, J[ohn] Ross. Adventures in the Apache Country: A Tour through Arizona and Sonora, with Notes on the Silver Regions of Nevada. New York, Harper, 1871. Print.

Crews, Michael Lynn. Books Are Made out of Books: A Guide to Cormac McCarthy's Literary Influences. Austin: U of Texas P, 2017. Print.

Chamberlain, Samuel. My Confession: Recollections of a Rogue. New York: Harper, 1956. Print.

Cormac McCarthy Papers, Southwestern Writers Collection, The Witliff Collections, Texas State U-San Marcos. 
Drake, James. James Drake. Intro. by Bruce W. Ferguson. Essay by Steven Henry Madoff. Poem by Jimmy Santiago Baca. Excerpts by Cormac McCarthy. Austin: U of Texas P, 2008. Print.

Flatow, Ira. “Connecting Science and Art.” NPR. 8 Apr. 2011. Web. 23 May, 2016. http:// www.npr.org/2011/04/08/135241869/connecting-science-and-art

French, Christopher. "James Drake: Towards the Pandemonium of the Sun." Glasstire. 2 Nov. 2006. Web. 23 May 2016.

http://glasstire.com/2006/11/02/james-drake-towards-the-pandemonium-of-the-sun/

Frost, Robert. "Design." The Poetry of Robert Frost. Ed. Edward Connery Lathem. New York: Holt, Rinehart and Winston, 1969. 302. Print.

Grimley, Terry. “Culture: American Honour for Artist Tift.” Birmingham Post 13 May 2008, first ed.: News sec. 13. Print.

Haeffner, Mark. Dictionary of Alchemy: From Maria Prophetessa to Isaac Newton. 1991. [London]: Aeon, 2004. Print.

Hirsch, François. "I find it very hard to talk about translations and about translating." Ed. Christine Chollier. Cormac McCarthy: Uncharted Territories / Territoires Inconnus. Reims, France: Presses Universitaires de Reims, 2003. 203-212. Print.

Hobbs, James. Wild Life in the Far West: Personal Adventures of a Border Mountain Man. Hartford, CT: Wiley, Waterman \& Eaton, 1872. Print.

Hughes, Robert. American Visions: The Epic History of Art in America. 1997. New York: Knopf, 1999. Print.

Jarrett, Robert L. Cormac McCarthy. New York: Twayne, 1997. Print.

Jurgensen, John. “Hollywood's Favorite Cowboy: Author Cormac McCarthy, 76, Talked about Love, Religion, His 11-Year-Old Son, the End of the World and the Movie Based on His Novel The Road." Wall Street Journal 13 Nov. 2009: W1. Print.

Krahn, Fernando. The Possible Worlds of Fernando Krahn. New York: Dutton, 1965. Print.

Levine, Lawrence. Conversation with the author. New York City. 17 Feb. 1996.

Luce, Dianne C. “Cormac McCarthy in High School, 1951.” Cormac McCarthy Journal 7 (2009): 1-6. Print.

---. “Blood Meridian's Death Carts and Angels of Death." Cormac McCarthy Journal 14.2 (Fall 2016): 227-232. Print.

---. “The Painterly Eye: Waterscapes in Cormac McCarthy's The Road." Ed. Nicholas Monk. Intertextual and Interdisciplinary Approaches to Cormac McCarthy: Borders and Crossings. New York: Routledge, 2012. 68-89. Print.

---. Reading the World: Cormac McCarthy's Tennessee Period. Columbia: U of South Carolina P, 2009. Print.

Madoff, Steven Henry. “Between Animality and Man.” Drake 8-21. Print.

Martinez, Jack. “New Cormac McCarthy Book, 'The Passenger,' Unveiled.” Newsweek, 15 Aug. 2015. Web. 19 Aug. 2017.

http://www.newsweek.com/cormac-mccarthy-new-book-363027

McCarthy, Cormac. Blood Meridian, or The Evening Redness in the West. 1985. New York: Vintage, 1992. Print. 
---. Cartoon self-portrait. Self-Portrait: Book People Picture Themselves: From the Collection of Burt Britton. Comp. Burt Britton. New York: Random House, 1976. 33. Print.

---. Editorial copy of revised final draft of The Orchard Keeper. 1963-64. Photocopied TS with editorial comments and McCarthy's holograph revisions. Box 2, folder 2, Cormac McCarthy Papers.

---. "First Draft" of Blood Meridian. c. 1981. Ts with holograph notes and revisions. Box 35, folder 9, Cormac McCarthy Papers.

---. Letter to Albert Erskine, received 31 Mar. 1964. Box 29, folder 3, Albert Erskine Random House Editorial Files.

---. Letter to Albert Erskine, received 15 Feb. 1968. Box 29, folder 8, Albert Erskine Random House Editorial Files.

---. Letter to Albert Erskine, received 8 Nov. 1968. Box 29, folder 2, Albert Erskine Random House Editorial Files.

---. Letter to Albert Erskine, received 12 Sept. 1978. Box 28, folder 8, Albert Erskine Random House Editorial Files.

---. Letter to Bertha Krantz, [fall 1985]. Box 29, folder 2, Albert Erskine Random House Editorial Files.

---. Letter to Bill Kidwell, postmarked Nov. 6, 1968. Heritage Auctions. 10 Apr. 2013. Web. 23 May 2016.

https://historical.ha.com/itm/books/cormac-mccarthy-typed-letter-signed-charlie-one-pagenovember-6-1968-plain-paper-watermarked-hammermill-bond/a/6094-36322.s?ic3=ViewItemInventory-BuyNowFromOwner-ArchiveSearchResults-012417\&lotPosition=0|15

---. Letter to Howard Woolmer, postmarked Maryville, TN, 17 Feb. 1970. Box 1, folder 1, Woolmer Collection of Cormac McCarthy.

---. Letter to Howard Woolmer, postmarked Nashville, 2 Feb. 1979. Box 1, folder 3, Woolmer Collection of Cormac McCarthy.

---. Letter to Howard Woolmer, postmarked Nashville, 5 Nov. 1979. Box 1, folder 3, Woolmer Collection of Cormac McCarthy.

---. Letter to Howard Woolmer, postmarked Albuquerque, 27 Jan. 1981. Box 1, folder 4, Woolmer Collection of Cormac McCarthy.

---. Random House Author's Questionnaire. [1968]. Box 29, Albert Erskine Random House Editorial Files.

---. Reading notes for Blood Meridian. Photocopy of unpaginated spiral notebook pages of holograph notes. Box 35, folder 5, Cormac McCarthy Papers.

---. "Whales and Men." Photocopied, spiral-bound TS with holograph corrections. Box 97, folder 6, Cormac McCarthy Papers.

McCarthy, Jennifer. “Jennifer C McCarthy, Outsider Artist, El Paso, Texas, USA.” Interview. Combustus. 4 May 2013. Web. 27 May 2016.

http://combustus.com/jennifer-c-mccarthy-outsider-artist/

Miller, Angela. The Empire of the Eye: Landscape Representation and American Cultural Politics, 1825-1875. Ithaca: Cornell UP, 1993. Print.

Morgan, Wesley G. “McCarthy's High School Years.” Cormac McCarthy Journal 3 (2003): 6-9. Print. 
Norris, Robert. "Piece of Art in Danger Downtown: Mosaic of Famous Author, His Friend in Way of Road." Daily Times [Maryville, TN] 16 Jul. 2000: A1, A6. Print.

Novak, Barbara. Nature and Culture: American Landscape and Painting, 1825-1875. 1980. Rev. ed. New York: Oxford UP, 1995. Print.

Owen, Mark. “McCarthy Is One of Nation's Most Remarked Young Authors.” Maryville-Alcoa Times 26 Feb. 1971: 4B. Print.

Peterson, Jordan B. Maps of Meaning: The Architecture of Belief. London: Routledge, 1999. Print.

Pickle, Betsy. “Artistic Return: Bill Kidwell Has Painted His Way around the World and Back Home Again.” News-Sentinel [Knoxville, TN] 1 Dec. 1988: B1-2. Print.

Texas and the War with Mexico. New York: American Heritage, 1961. Print.

Theroux, Alexander. The Strange Case of Edward Gorey. Seattle: Fantagraphics, 2010. Print.

Tift, Andrew. Andrew Tift: Portrait of a Blog. "Smithsonian Institution Purchase 2 of My Paintings." May 5, 2008. Web. May 24, 2016.

http://www.andrewtift.co.uk/portrait-artist/2008/05/05/

Whipple, Amiel Weeks. The Whipple Report: Journal of an Expedition from San Diego, California, to the Rio Colorado, from Sept. 11 to Dec. 11, 1849. 1851. Los Angeles, Westernlore, 1961. Print.

White, Christopher. "Reading Visions and Visionary Reading in Blood Meridian." Ed. Rick Wallach. They Rode On: Blood Meridian and the Tragedy of the American West. Casebook Studies in Cormac McCarthy, Vol. 2. Miami: Cormac McCarthy Society, [2013]. 177-190. Print.

Wilhelm, Randall. “All the Pretty (Picture Book) Horses: Cormac McCarthy as Verbal Illustrator.” Ed. Rick Wallach. Beyond Borders: Cormac McCarthy's All the Pretty Horses. Casebook Studies in Cormac McCarthy, Vol. 3. Miami: Cormac McCarthy Society, 2014. 334-360. Print.

---. “'Golden chalice, good to house a god': Still Life in The Road.” Cormac McCarthy Journal 6 (2008): 129-146. Print.

Williams, J. R. Cowboys Out Our Way. New York: Scribner's, 1951. Print.

Woodward, Richard B. “Cormac Country.” Vanity Fair Aug. 2005: 98, 100, 103-104. Print.

Woolmer Collection of Cormac McCarthy. Southwestern Writers Collection, The Witliff Collections, Texas State U-San Marcos.

\section{NOTES}

1. See Wilhelm (2008 and 2014).

2. In "Cormac McCarthy in High School," I drew inferences about McCarthy's senior year in high school based on the Gold and Blue graduation issue of 1951, which was misfiled in the school's archive when Morgan visited it. Catholic High School graduate Robert Gentry shared this issue with me from his personal collection. Recently Eric Theodore, a student of Stacey Peebles, searched the archive of the Gold and Blue for drawings and writing by McCarthy, and he unearthed a lightly humorous dialect poem, "Sportsman's Wish" (Nov. 1948: 2) and a sly prose account of McCarthy's visit to the fair in Chilhowee Park with friends, "Two-Hour Scholar Loses His Dollar," dated September 29, 1950-but no signed artwork. 
3. This letter may tentatively be dated by McCarthy's reference to the reviews of Blood Meridian that he and Krantz had been exchanging. McCarthy enclosed one from Sewanee Review, in which Walter Sullivan reviewed most of his first five novels in the fall 1985.

4. When McCarthy filled out an author's questionnaire for Random House in preparation for the publication of Outer Dark, he wrote that in Europe, he had "lived in Paris \& on the island of Ibiza, in the Balearics, Spain (for 1 year). Otherwise traveled in Ireland, Eng. France, Spain, Italy, Switzerland..."

5. The map appeared as endpapers in the first hardcover edition of Blood Meridian.

6. On August 5, 2015, Drake participated with McCarthy in a live multimedia program that included a reading from McCarthy's unpublished novel The Passenger, a prerecorded introduction to the novel by McCarthy, and original music by his son John Francis. The program also featured a discussion between Drake and David Krakauer, President of the Santa Fe Institute, focused on affinities between Drake's work and McCarthy's (Martinez). The program seems very much a collaboration of friends and family.

7. The poem is evoked again and more explicitly when the kid observes the battle of the Glanton gang against Elias' troops from his elevated position in the mountains: "the collision of armies remote and silent upon the plains below" (213).

8. See for example Pollock's Number 1, 1950 (Lavender Mist), aluminum, oil and enamel on canvas. Hughes remarks of this work and the similar Autumn Rhythm (1950), "There is more than a mere memory in them of the epic space which nineteenth-century artists had found in American landscape: they are expansive, full of wind and weather, shifts of light, and ceaseless mutation" (486).

9. For McCarthy's deployment of the iconology of the shipwreck in The Road, see Luce, "Painterly Eye" (70-75).

\section{ABSTRACTS}

This study argues that in Blood Meridian (1985) McCarthy creates landscape scenes that function as narrative commentary on the Glanton gang's Indian-fighting, on America's pursuit of Manifest Destiny, and on humanity's innate aptitude for violence. The article surveys the biographical evidence for McCarthy's interest in the visual arts, then inventories the language of art in Blood Meridian and explores the novel's allusions to specific artworks. It culminates in readings of several scenes in which the narrator interprets the landscape before him in moments of sober contemplation. Each of these scenes bears a title reminiscent of painted landscapes, such as "Under the Animas peaks" or "Night scene with moon, blossoms, judge." Each comprises a static composition that slows the violent action and also functions as a prose poem, rich in allusiveness. Evoking in the reader the perceptual and interpretive modes of a pensive viewer of a painted landscape, these scenes invite us to apply techniques drawn from art criticism to comprehend them as the narrator's sober meditations on the Glanton gang's violent enterprise. 
INDEX

Keywords: Blood Meridian, visual arts, landscapes, ethics, biography.

\section{AUTHOR}

DIANNE C. LUCE

Dianne Luce holds Faculty Emeritus status from Midlands Technical College in Columbia, SC. She is one of the founding members of the Cormac McCarthy Society and has served as Vice President, President, and bibliographer for the Society. She is co-editor, with Edwin Arnold, of two collections of work on McCarthy and author of Reading the World: Cormac McCarthy's Tennessee Period. Since completing that book her research interests have focused on archival studies and on McCarthy's engagement with the visual arts. Luce's work on the archives has been published in two articles in Resources for American Literary Studies; and her "Projecting Interiority:

Psychogenesis and the Composition of Outer Dark," a revision and expansion of her keynote address at the 2016 McCarthy conference in Berlin, will appear in the spring 2018 issue of theCormac McCarthy Journal. 